\title{
CONSUMER RESEARCH PROCESS AND UNDERSTANDING BUYING BEHAVIOR POST COVID -19
}

\author{
Tamoghna Mandal \\ Department of Fashion \& Technology \\ Amity University, Kolkata, West Bengal, India
}

\begin{abstract}
In this paper we will be discussing on the changing consumer behavior attitudes and bring up a comparison of Pre- and Post-COVID consumer buying habits and what are the attributes where the consumers make a choice of their decision. The study aims on finding the relationship of the buyer and consumer in Fashion Retail market structure and helps us to find the changes the world has noticed after the rapid pandemic outbreak.
\end{abstract}

Keywords - Consumer behavior, Retail changes Post COVID19 , Consumers buying behavior.

\section{INTRODUCTION}

In Pre-COVID times consumerism was meant for mere buying products for meeting daily satiable needs not thinking much of taste and preferences which was more of a conjectured buying habits except for few better consumers understanding buying needs and value authenticated products. The sole concept of the manufacturing units was idealized on various easy and nonpremeasure production techniques and methods for easy consumption based on sense gratification and fast filling profits varying from different class of people of different economy. Low priced, low quality products were also accepted in early retail days hundred years ago but later the consumers became aware of the fact that the consumption of goods should be of higher quality and services. (William T Robinson, 1985). This quality approach was supported by the selling approach where aggressive selling took over and consumers were just used as means to sell for the profitability. (Leone, 1991) By the middle of the twentieth century, more and more organizations began to feel the need of understanding customers and the consumers began to resist mass production. People came in contact with the outside world with open ended discussions ,media provocative advertorials, developing buying taste and habits, induced cognitive and behavioral process, and constant evaluation of the products in the basis of quality and quantity and of course post -buying behavior to retain with the products in the mere future or switching to a different products with same satisfying variables This change of behavior leading to a concrete Consumer preference which led to the rise of consumerism, innovation product, rise of direct and indirect competition, changing lifestyles, increased international trade and marketing -oriented approach along with united decisionmaking groups like family or organization (MIchael Storper, 2009).But sudden change after widespread pandemic outbreak the procedure of consumer demands is now to be understood and new choices are being made or will be made to understand each product on the basis of safety, and this will lead to a era of "new normal development" in the field of consumer behavior. In this paper we will be discussing on changing consumer behavior and attitudes post COVID 19, why do we need to understand consumer buying habits, consumer as a decision maker Post COVID times, consumer retailing thoughts in and after 2020, post COVID Consumer motives of buying.

\section{THE UNDERSTANDING OF THE CHANGES OF BEHAVIOUR (NOW AND THEN)}

Consumer behavior is a scientific study and analysis on how to understand how the psychology of the consumers towards a certain goods and commodities and their buying decision and post buying behavior. product, consuming and disposing it by taking a decision. It deals with the understanding of the aspects of purchase and consumption of goods and services by all individuals with the challenge of understanding the psychological and social variables which plays an important role in decision making. This process is related to the behavioral and cognitive understanding while making purchase decisions. The consumer behavior understands why, how and when and what to buy. It includes post purchase behavior, disposal of purchased products, diffusion, innovative approach, role and goal of marketers and understanding the various buying process. (PM Rath, 2014) However with the outbreak of the Corona Virus the buying habits and attitudes are changing and it will remain unchanged post pandemic. Now in this year 2020, most customers are focused on buying the basic needs with more conscious shopping plan, going out less than often, buying local purchases and embracing the digital commerce and also to connect with digital learning and working platform been taken as a necessity and of course not to mention, work from home. 


\section{International Journal of Engineering Applied Sciences and Technology, 2021 \\ Vol. 5, Issue 10, ISSN No. 2455-2143, Pages 186-192 \\ Published Online February 2021 in IJEAST (http://www.ijeast.com)}

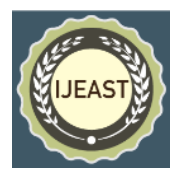

Every time consumers need to buy products suited to individual taste and preferences. The process of acquiring a product, consuming the product and understanding the product in aspect of purchase and consumption with the variables of social cultural and psychology can be defined as consumer behavior (G Muruganantham, 2013). This consumer behavior is not only subjected to individual purchasing preferences but also related to group decision-making like families and organizations. Now that the ongoing pandemic has taught us to be more cautious and selective in buying our consumer needs with is more inclined towards safety rather than impulse or luxury buying. Now due to this sudden unexpected outbreak suddenly the organizational purchasing habits will cater a whole new demand of the final customers and will include $\mathrm{mas}$ s i ve $\mathrm{change}$ in organizational buyers like governmental bodies, manufacturing units, service providers, marketers of product and services etc.

\section{NEW BEHAVIORAL PATTERN FORESEES THE FUTURE}

The COVID-19 pandemic has conditionally changed the world in a term used as "the new normal". People are counting to live a life which is unknown with changing, buying habits and change of thinking pattern which is focusing more on the safety issues than living life on the edge as it was before. Supply chain, retail stores are shutting down and they are beginning to feel that in order to hold back customers and enticing them and they need to think differently as customers will now not think of walking in to any retail stores but rather choose to use digital platform mode to chip in for their choices. The virus has redesigned the entire buying pattern behavior and the consumer industry in quick time and space. Consumer behavior largely depends on psychology and current influences of the world through advertisement, socio-political influences, natural and sudden calamities, and demand and need of the product and supply. As this year 2020 is attacked by the pandemic NOVEL CORONA virus the buying behavior is mostly focused on staple and hygiene products and services and restricting ourselves in buying goods and commodities which are less important. It is possible to influence a consumer to change their product which were they were acquainted with for long time consumption and it's also socially acceptable to influence consumers too. Consumer behavior all age and gender groups and is also getting affected by the pre conceptualized buying and consuming habits and must adapt a new pattern. This change includes cumulative decision in nuclear families, adapting the change in human lifestyle. Diversified tastes and preferences, increasing level of stress due of fear of virus attack, leading to the growth of health regime products and tremendous growth of ecommerce, M-commerce and F-commerce are also helping sustaining consumer needs soon.

\section{CONSUMER AS A DECISION MAKER}

This is understood that the understanding the important models like Howard-Seth model (JU Farley, 1970) and Nicosia Model which helps in predicting consumer decision making will and must change. The Howard-Seth Model of buying behavior deals with Inputs or information cues acting as a stimulus related to the physical attributes of the product, the verbal and nonverbal elements and the third is the information's been provided by the potential customers in a social surrounding when they meet each other. Then it is followed by the motives of the purchase, awareness, attitude buying intention and post purchase feedback. However, the Nicosia model is based on the feedback derived by the marketeer based on various social economic factors like awareness, motivation, attention, and perception. It's also important to discuss and know the role of consumer decision making and problem to be solved which consumers deciding. Store \& non store-based retailing along with post purchase behavior in retailing along with the nature of organizational buying, the internal and external factors in affecting the buying process are also important factors to understand the process of understanding consumerism.

(R Da Silva, 2002). However, Consumers are now deeply concerned about the global impact of COVID-19, hygiene and economic wise. The consumer response to this sudden situation is making people worried with a panic button pressed in storage of staple and hygiene products. On the other end some consumers remain apathetic to this rising crisis and are continuing their business as usual, despite alarm and Law enforcement from their government and health professionals. According to a survey on 100 people in cooperative society housing Estate of a population of 1200 in Salt Lake West Bengal it was found that the people and now focusing on -:

1. Building personalized hygienic products \& Localized products

2. Care and safety catalogues to gain customer trust.

3. Digital commerce

4. Food and medical security

With this Survey the brands and manufacturing units will need to focus on -:

1. Products highlighting health and hygiene safety strategy.

2. Sustainable production.

3. Locally made or Artisanal products.

4. More digital product information and mode of communication. 


\section{CONSUMER TOP PRIORITIES SINCE FEB} 2020

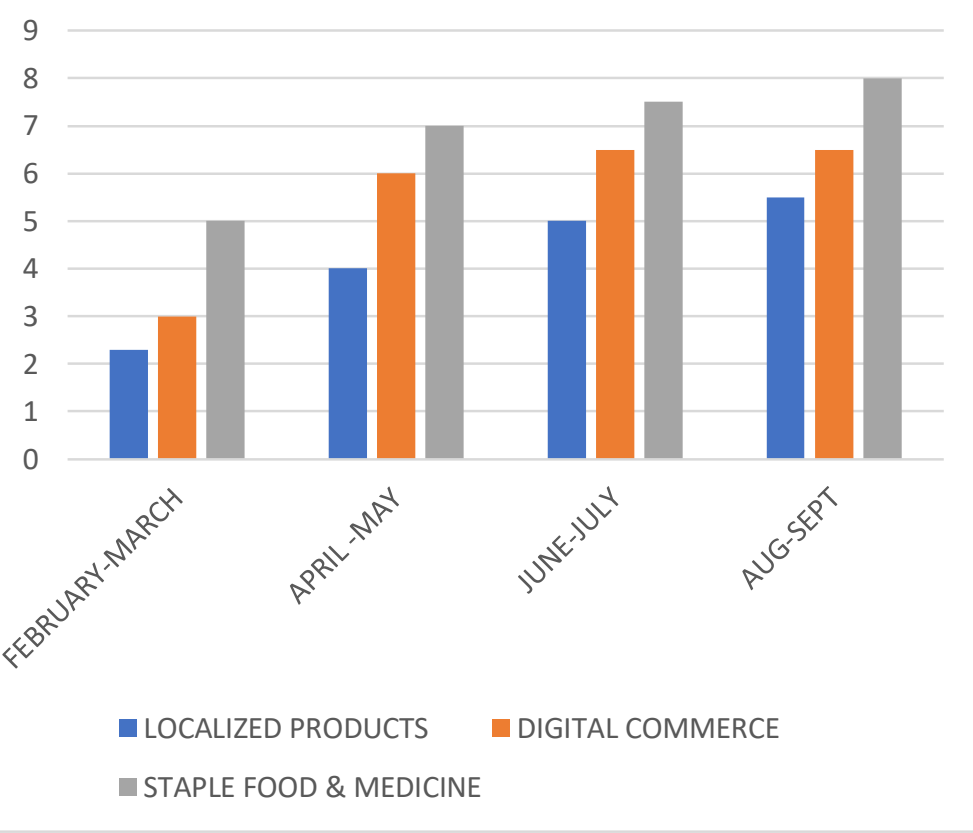

Table-1.1-: This bar graph analysis suggests that there has been an increase of 3 most important determinants during COVID times since February this year and same has been anticipated for August-September but the rise of graph is also in the same rate where staple food and medicine are on high demand followed by digital commerce and localized products.

\section{DIFFERENT TYPES OF CONSUMER RETAILING AND THEIR SPECULATED CHANGING HABITS IN TERMS OF HYGIENE FOR CUSTOMER SAFETY.}

Due to this pandemic outbreak the store concept will now adapt changes in services like internet which his likely to be the most preferred mainly for the items as per order of demand are as follows -;

1. Grocery and staple Products.

2. Dairy products

3. Medicine and hygiene products

4. Mobile and electronics

5. Crockery and Upholsteries

6. Liquor.

Other store marketing concept which deals with selling and distribution of merchandise related to products like garments and clothing electronics, accessories, jewelries, upholsteries, furniture, hold a low market demand at this weeing hour. The consumer reach will see a new approach in different types of retailing like sales retailing (Avon, Oriflamme, Amway, Eureka Forbes), Direct Mail marketing, Catalog Marketing, Tele-Marketing, Media and Internet Marketing (Television commercials and Amazon.com, Flipkart.com Myntra .com), In-store marketing, etc. Among all these, the store-based retailing is the cynosure of all retail types after the arrival of big names like Shoppers Stop, Pantaloons, Aditya Birla Group, Big Bazar etc needs a whole new concept like In- build hygiene in garments, safety concern of walk in consumers etc. Street market is few more retailing concepts which are carried out have the least hygienic sense are less preferred by educated consumers but still on high on sales due

Below table has the comparability of choice of store types by the consumers pre and Post COVID -19

Table 1.1: Different Type of Store Format choices of consumers Pre- COVID 
International Journal of Engineering Applied Sciences and Technology, 2021

Vol. 5, Issue 10, ISSN No. 2455-2143, Pages 186-192

Published Online February 2021 in IJEAST (http://www.ijeast.com)

\begin{tabular}{|c|c|c|c|c|c|c|c|}
\hline $\begin{array}{c}\text { Types of Store } \\
\text { (Organized/Unor } \\
\text { ganized) }\end{array}$ & $\begin{array}{c}\text { Characteristics/Types } \\
\text { of assortments. }\end{array}$ & $\begin{array}{c}\text { Footfall } \\
\text { (per day) }\end{array}$ & $\begin{array}{l}\text { Area } \\
(\mathrm{S} \mathrm{q} \\
\mathrm{Ft})\end{array}$ & Services & Prices & $\begin{array}{l}\text { Indian } \\
\text { Brands }\end{array}$ & International Brands \\
\hline $\begin{array}{l}\text { Specialty Store } \\
\text { (In mall) }\end{array}$ & $\begin{array}{l}\text { Single brand and } \\
\text { product procurement }\end{array}$ & $50-100$ & $\begin{array}{l}500- \\
1000 \\
\text { sq ft }\end{array}$ & excellent & $\begin{array}{l}\text { Moderately } \\
\text { high }\end{array}$ & yes & No \\
\hline $\begin{array}{l}\text { Departmental and } \\
\text { super Market }\end{array}$ & $\begin{array}{c}\text { Multiple } \\
\text { merchandising lines } \\
\text { /Wide range of } \\
\text { different assorted } \\
\text { products }\end{array}$ & $1000-2000$ & $\begin{array}{c}20,00 \\
0- \\
50,00 \\
0\end{array}$ & moderate & moderate & yes & yes \\
\hline $\begin{array}{l}\text { Discounted } \\
\text { Stores }\end{array}$ & $\begin{array}{l}\text { All discounted /end of } \\
\text { season items }\end{array}$ & $200-700$ & $\begin{array}{l}250- \\
400 \\
\text { Sqft }\end{array}$ & $\begin{array}{l}\text { Moderate to } \\
\text { good }\end{array}$ & $\begin{array}{l}\text { Reasonable } \\
\text { being } \\
\text { discounted. }\end{array}$ & yes & yes \\
\hline Street Market & Unorganized market & $\begin{array}{l}1000 \\
\text { above }\end{array}$ & $\begin{array}{l}100- \\
200 \\
\text { Sqft. }\end{array}$ & $\begin{array}{l}\text { Below } \\
\text { standard }\end{array}$ & $\begin{array}{l}\text { Low and } \\
\text { affordable }\end{array}$ & yes & $\begin{array}{c}\text { Fake items may } \\
\text { available }\end{array}$ \\
\hline E-commerce & $\begin{array}{l}\text { Self-service multi- } \\
\text { choice options for } \\
\text { each product }\end{array}$ & $\begin{array}{l}\text { Can't be } \\
\text { predicated }\end{array}$ & & $\begin{array}{l}\text { Moderate to } \\
\text { excellent. }\end{array}$ & $\begin{array}{l}\text { Moderate to } \\
\text { high. }\end{array}$ & yes & yes \\
\hline
\end{tabular}

Adapted from ET knowledge series: Retail 2001-2002,34-37

Table 1.2: Different Type of Store Format choices of consumers Post- COVID

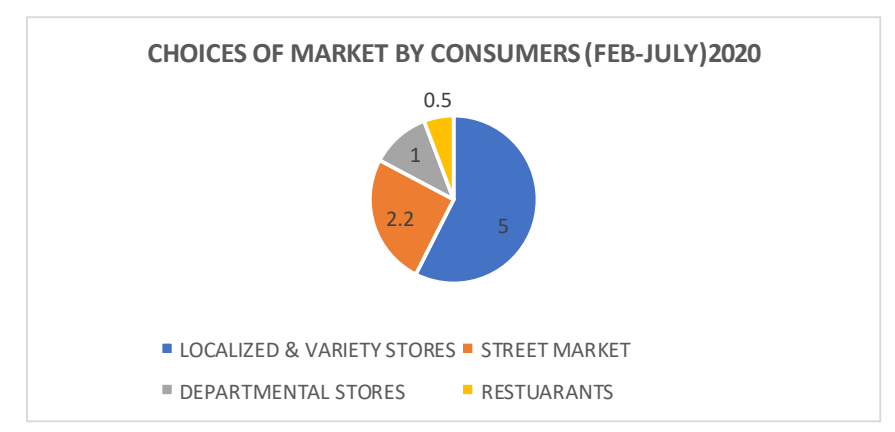

Table 1.2-; This Pie chart suggest that the choice of buying localized products inside community area (within a range of 1$2 \mathrm{~km}$ ) is most preferred followed by street market (flowers, fruits and other household necessities) followed by departmental stores visit which is very less and the most minimal visiting place is restaurants and hotels which are opened but still lagging behind in making profitable business.

It is therefore likely to be expected that the future marketing and sales breeding ground would be E-commerce for new or low frequency users. Other stores are been avoided as there has been a surmountable change in discretionary income and spare time, and reconsidered values and priorities.
If we look at the very current situation where the whole world is attacked by the pandemic outbreak, COVID-19 virus, the people are now focused mostly on safety needs based on mental peace and heath satisfactory measures along with Physiological needs like food, water but sans clothing, rather than need for Affiliation and egoistic needs. Now its high time where the companies needs to increase their attention on focus on digital tools to be engaged with consumers and increase sales relationship so that the consumers need not to step out from their home due to severe lockdown measures by the government yet they will be satisfied with their desirable product at home by online mode of payment and delivery. The common human needs had been enlisted by Abraham $\mathrm{H}$. Maslow in 1943 is still there which cannot be denied where humans generally try to satisfy their needs from the lowest level beginning from Physiological and ending towards Self fulfilment but the new normal has changed all . (Straver, 1977).

\section{NEEDS CONCERNED with SOCIAL INTERCOURSE}

Adapted from Henry Murray- "Types of human Needs", David C. McClelland, Studies in Motivation.

According to this theory of Murray, this needs not only influence the behavior of the person but also gives an insight to a human personality. Based on this perspective people prioritize their human needs. These motives are called the "press" motives as they often press the people to act accordingly. For ex: A KFC chicken advertisement if seen by a person will press him or her to go and buy for it to quench his 


\section{International Journal of Engineering Applied Sciences and Technology, 2021 \\ Vol. 5, Issue 10, ISSN No. 2455-2143, Pages 186-192 \\ Published Online February 2021 in IJEAST (http://www.ijeast.com)}

or her taste even if he or she is not hungry. Therefore, some consumers are even risking their safety hazards when they are choosing to slay their boredom by ordering online food delivery services like Swiggy, Zomato, which might be hazardous if the delivery and preparation are not maintained with safety norms during this crisis hour.

Amongst all the lists from the adaptation theory of Henry Murray, the need of achievement, acquisition and recognition were found to be the most prominent in the influence of human behavior which has changed during the pandemic outbreak.

\section{INVOLVEMENT AS AN IMPORTANT PART OF CONSUMER BEHAVIOR}

When motive is met during COVID days, another important factor playing a huge role in effecting consumer needs now is involvement. Often, we see, a young adult is spending much of his time in analyzing, researching, surfing, and meeting experience people for buying his first mobile phone or watch out of his own salary or pocket money. Now it seems that involvement is more overpowered by needs of entertainment like Netflix, Amazone prime, Disney Hotstar. Other needs like online education, news and healthcare regime from home is growing among young generations. On the other hand, those days are gone when for picking up household furniture the same person just goes and picks as ordered by his parents without much analyzing the type of wood, design and durability for the furniture. So, involvement is important when a product is more likely of your choice and for anyone to use for personal benefit and if the product is costly. Involvement defines- 'a person's perceived relevance of object based on their inherent needs, values and interests". (Kim, 2005)

As a person gets deeply involved in the product when he or she perceives a link between the product and interest and needs. Henceforth, the ideology is that more relevant the product is for an individual, the more involvement a person gets with it.

When an involvement is higher, (like now more of health and hygiene products like sanitizers, hand wash, hand sprays, gloves and masks and PPE are on high demand) then the marketers gets more into finding related information about the product which will benefit the customers with more trust and being more inclined and loyal. The customers start to use cognitive measures in finding a product knowledge (such as price, USP, features etc.) and uses various means like net surfing, watching advertisement, reading magazines and news of the product. The emotional bond previously created is now missing because there is serious need than emotional need to understand buying behavior. As stated by Jamie Oetting (Oetting) as she found "when Coca-Cola recently changed its tagline from "Open Happiness" to "Taste the Feeling," it maintained its focus on happy images of people connecting and engaging one another, such as the below ad showing the bond between siblings".

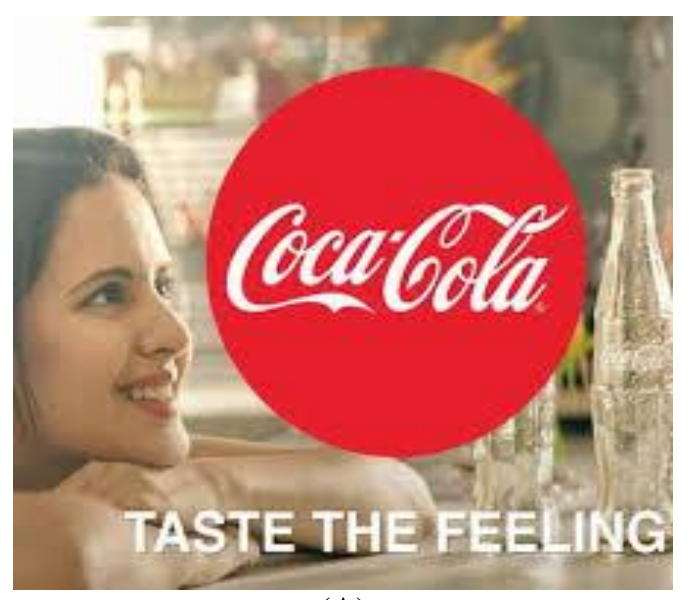

(A)

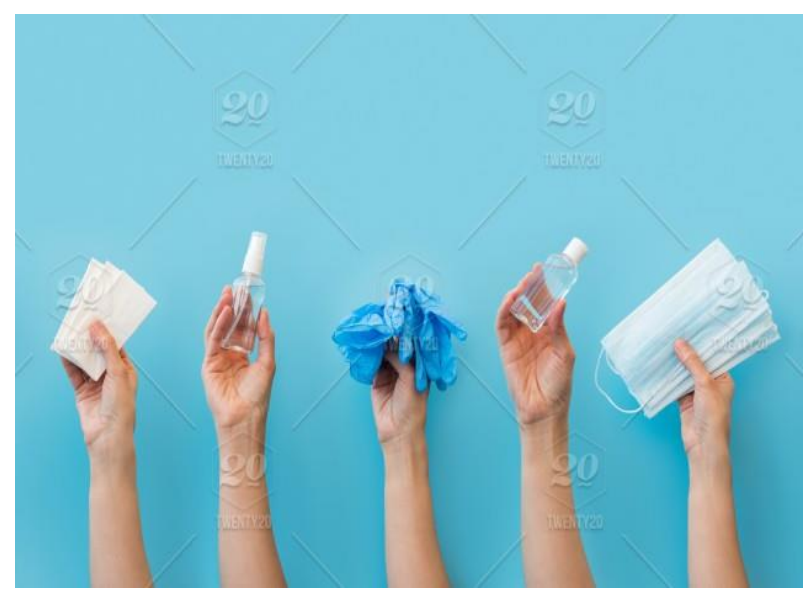

(B)

Fig 1:2; -: (A) Coca Cola; Taste the Feeling Advertisement for Indian Consumers vs (B) Health and hygiene products.

Here in this picture we see, consumers are now more concerned with buying health hygiene products than pleasure aerated drinks which defines change of buying behavior.

\section{Measurements of attitudes: Semantic Diffential Scale}

Measurement of Attitude helps the marketers to understand how the consumers will behave towards the market. Attitude can be measured by using certain sales like Semantic differential scale and Likert Scale of measurement. (Soh, H., Reid, L. N., \& King, K. W. 2009)

A semantic differential scale was used as a study to compare 2 leading newspapers in Kolkata amongst 100 people providing information on Current COVID news Sanctity as newspapers are the only hope of surveillance for people who are home locked since March 2019 in India. Even if the choice of one product is superior it doesn't mean that the other direct competitors will go on a halt. They need to improve on the 
desirables which will prompt them to sustain a better consumer diversification for a good market to capture.

Tab 1.2: A Semantic Differential Scale for Measuring the
attitudes of Respondents on a
Newspaper giving more COVID related information.

Times of India VS Telegraph

5 -point scale on bi-polar categories (Semantic Differential Scale).

$\begin{array}{lllllllllll}5 & 4 & 3 & 2 & 1 & 0 & 1 & 2 & 3 & 4 & 5\end{array}$

1. Updated News on COVID VS Old news on COVID

2. Exclusivity of Political

News coverage VS Limited political covered news

\section{News on Casualty and affected report VS No News on casualty and affected report}

4. Vivid Information on International Business and World Market,

Share Stock, Broker news VS

Less

Important Business and World News

\author{
5. Bringing depth on Indian \\ COVID informative updates VS No depth of Indian COVID \\ informative updates.
}

This method of survey is extremely bipolar in nature and a measurement scale is inserted to measure the two extreme levels. Some bipolar levels are like cheap/costly, $\mathrm{good} / \mathrm{bad} /$ expensive/affordable etc. It is used to measure the consumer perception for certain choices of similar usage or product USP. In the above Survey the measurement was considered amongst 2 influential papers in a big metropolitan city like Kolkata and it was conducted over 100 regular people who ae the subscribers of both these papers and it was found that Telegraph has a better choice over Times of India regarding exclusivity of news coverage and in terms of bright colorful and catchy news and presentation. It is also found that Telegraph is more appealing to the masses with better information to World political news and market upgrade. Thus this type of survey helps to understand the reason of consumer attitudes beliefs and choices and it throws a definite chance to the marketeers and brands to change their opinion and view in setting up a better customer satisfaction in order to stay as $\mathrm{s}$ front runner among many fierce direct competitive market.

\section{CONCLUSION}

The entire behavioral buying approach is based on the kinds of attitudes of people having towards money and superbly influenced by the various modes of Communication like advertorials, brands equity, spending pattern, quality of life, family income etc. Marketeers generally tend to grab the attention of affluent customers but in recent times the focus is also on lower- and middle-income groups. Everything that a market and brand commutes through their style of promotion to gain product profit it's always the consumers to choose what why and when to buy our essential products. The consumer may get driven by sheer motivation or influential features of a product but there is always a strong need to study the entire marketing approach and analysis for each product and in the end helping our self from being deceived and embittered by improper businesspeople.

However now as the world has seen the plight of the virus outbreak, the insights of visual ads and brands popularity and loyalty cannot help in analyzing the buying problem and the consumers has become more alert on health and hygiene issues and become more conscious on the choices the will now make according to their new needs for fulfillment as they now won't be driven on the basis of motivation, innovation of brands, choices been made, perception and attitude. There is also a gradual development on new brand personality and consumer approach. Personality approaches like Freud and Jung and their relationship with the loyalty of the brand is very important which needs in built Hygiene elements to retain customer belief. Now that the market place is not the only intriguing factor which determines the place of consumer buy and their choice of outlet but online or digital determinants and omnichannel capabilities as well and there will be a strong cognitive and behavioral process not only based on individual choices and buying behavior but also depends on other buying behavior units like an organization or family. Therefore, a consumer research is still a constant search, evaluation consumption and post purchase behavior and appraisal of each products keeping in the geographical environmental changes along with personal characteristics in mind. Retailers focus will be on shopping efficiency, both online and offline. As the world is longing for a return to normalcy, but the reality is, the determinants of consumer and retailer's relationship has changed. as we know it has changed.

\section{REFERENCE}

1. Bashar S. Gammoh, K. E. (2011, April 22). Consumer evaluation of continuous and discontinuous innovation: The effects of brand equity and product category knowledge. American Journal of Business.

2. G Muruganantham, R. B. (2013). A review of Impulse buying Behavior. International Journal of Marketing. 
3. JU Farley, L. R. (1970). An Empirical Test of the Howard-Sheth Model of Buyer Behavior. Journal of Marketing Reserach.

4. Kim, H. ( 2005). Journal of Fashion Marketing and Management:

5. Lather Anu Singh, K. T. (2006). Shopping malls: New retail formats keeping pace with the shoppers' mood. The Journal of Indian Mangement \& Stategy.

6. Leone, F. J. (1991). Implicit Price Bundling of Retail Products: A Multiproduct Approach to Maximizing Store Profitability.

7. MIchael Storper, A. J. (2009). Rethinking human capital, creativity and urban growth. Journal of Economic Geography, 147-167.

8. Oetting, J. (n.d.). Emotional Advertising: How Brands Use Feelings to Get People to Buy.

9. PM Rath, S. B. (2014). The why of the buy:consumer behaviour and Fashion Marketing. Bloomsbury Publishing.

10. R Da Silva, G. D. (2002). Assessing the influence of retail buyer variables on the buying decision-making process. European journal of marketing.

11. Straver, W. (1977, February 1). The International Consumerist Movement. European Journal of Marketing. 12

12. William T Robinson, C. F. (1985, August 1). Sources of Market Pioneer Advantages in Consumer Goods Industries.

doi:https://doi.org/10.1177/002224378502200306 